\section{Physics centre re-launches search for new director}

Munich. Praveen Chaudhari, a Pakistan-born senior physicist at IBM's Thomas Watson Research Center in New York, last week formally turned down the directorship of the International Centre for Theoretical Physics (ICTP) in Trieste, northern Italy, after more than six months of negotiations had failed to achieve agreement on the terms of his contract.

Speaking during an earlier visit to India, Chaudhari said that he had withdrawn for "personal" reasons unrelated to the nature of the position. He said that he could have taken up the post next year, but that at present it was "not possible" to move from New York.

The loss of Chaudhari, who had been a popular choice, is a blow to the International Atomic Energy Agency (IAEA), which established the centre in 1964 to provide high-level training for physicists from degovernment, which pays around 90 per cent of the ICTP's costs, approved the transfer of administrative responsibility for the centre from IAEA to the United Nations Educational, Scientific, and Cultural Organization (Unesco) in 1996, and IAEA is keen to have a new director in place by then.

The new director will succeed Abdus Salam, the ICTP's first - and so far only director, who retired last year at the age of 78. Under Salam's guidance, the budget of the centre has increased from US $\$ 350,000$ when it was founded to more than US\$20 million, and it now receives more than 4,000 visiting scientists, mostly from developing countries, each year.

The search committee that put forward Chaudhari's name - made up of two representatives each of the Italian government, Unesco and IAEA, and two members of the centre's science committee - has now been reconvened. According to sources within the IAEA, the committee is unlikely to recattract sufficient support. hind the scenes. cist like himself. Democrat governments. after that. veloping countries. Last month the Italian

ommend a second name from the original short-list of four candidates, all citizens of developing countries, as none is likely to

Although there is no rule specifying that the director should be from a developing country, it is widely expected. But some scientists have been concerned about pressure from the Italian government to secure the appointment of an Italian scientist. Although denied by the IAEA and members of the selection committee, it is clear that there has been some attempted manoeuvring be-

Antonino Zichichi, for example, director of the World Laboratory, which was set up in 1986 in Switzerland and receives twothirds of its budget from Italy, says he has been approached "many times, by the Italian government, the search committee and the science committee" to allow his name to be put forward. He says that he declined because the director should be a theoretical physicist, rather than an experimental physi-

ICTP has always had to survive in an intensely political environment. In the early 1960 s, as the Cold War gathered momentum, the Italian government successfully bid for the centre to be built in Trieste, close to the border with the former Yugoslavia, to help prevent the town from becoming isolated. Since then the centre has received generous support from successive Christian

With the fall of the Christian Democrats, however, its close political connections with Rome have been severed. In the current political uncertainty, continued funding on the generous levels of the past can no longer be taken for granted. Financing is secure until the end of 1998. But a new law will be needed to continue funding for the centre

Alison Abbott and K. S. Jayaraman

\section{DNA repair, sry gene share Jeantet prizes}

London. Five researchers will share a total of more than 2 million Swiss franes (US\$1.5 million) awarded for this year's Louis Jeantet prizes for medicine, launched in 1986 and intended to boost innovative biomedical research in Europe.

Two of the three prizes are shared by pairs of scientists. One has been awarded to Dirk Bootsma and Jan H. J. Hoeijmakers of the Erasmus University of Rotterdam, in recognition of their pioneering studies of the DNA repair system through the analysis of several human diseases involving genetic instability.

The second pair are Peter Goodfellow of the University of Cambridge and Robin Lovell-Badge of the Medical Research Council's National Institute for Medical Research in London. They have been recognized for their joint discovery of the testis-determining gene sry, which plays a basic role in sex determination in humans.

The third Jeantet prize has been awarded to Peter Gruss, director of the department of molecular and cell biology at the Max-Planck Institute of Biophysical Chemistry in Göttingen, Germany, for his contribution to the understanding of embryonic development in vertebrates. $\square$

\section{French committee to link research to 'national interests'}

Paris. Edouard Balladur, the French prime minister, last week formally appointed the 15 members of a new committee established to advise the government on medium- and long-term national research strategy (see Nature 373, 9; 1995).

The main tasks of the so-called Committee for Strategic Orientation (COS) will be to prepare an annual report on the state of French research, to be debated in the National Assembly each year before the budget vote. According to François Fillon, the minister of research and higher education, the aim is to ensure that government research policy corresponds to "national interests".

In practice, the full committee will meet only two or three times a year. But it will have a secretariat and be able to set up external working groups. It will also be able to commission reports from existing bodies, such as the Commissariat général du Plan, a powerful agency that makes recommendations to the government on all areas of public policy.

At its first meeting last week, the committee elected Pierre Faurre, the chairman of the boards of the large electrical and mechanical engineering company SAGEM and the Ecole Polytechnique, as its chairman.

Faurre is one of just four industrialists on the COS, a lower proportion than in other countries. Fillon says that having more industrialists would have undermined its legitimacy in the eyes of the research community.

The COS's other members include André Giraud, the head of the Scientific Council for Defence and former head of the French Atomic Energy Commission, and Jean-Marie Lehn, who shared the 1987 Nobel prize for chemistry.

Life sciences are represented by Pierre Chambon, director of the Institute of Genetics and Molecular and Cell Biology in Strasbourg and Axel Kahn, director of the INSERM Laboratory of Research on Genetics and Molecular Pathology at the Cochin Institute in Paris. The committee also includes Pierre-Louis Lions, a recent winner of the Fields medal in mathematics.

Although the creation of the committee has been welcomed in many quarters, there is some concern that its activities will conflict with those of the ministry's existing advisory body, the Conseil Supérieure de la Recherche et de la Technologie (CRST).

Fillon acknowledges such concern, but claims that each committee has a distinct remit. Whereas the COS will work directly for the government, CRST will continue to act as a "parliament" to represent the views of the research community to the government, he says.

Declan Butler 